\title{
Measures of Organizational Training in the Capability Maturity Model Integration (CMMI)
}

\author{
Mahmoud Khraiwesh \\ Faculty of Information Technology \\ Zarqa University, ZU \\ Zarqa, Jordan
}

\begin{abstract}
Training has a major impact on organizational commitment. Organizational objectives can be met by executing several training strategies and programs to enhance training. Organizational training aimed at developing employees' knowledge and skills. It shall enable employees to carry out their duties efficiently and effectively. Two goals and seven practices of the organizational training process area in the capability maturity model integration (CMMI) framework are analyzed through this study. That's done to set common measures for organizational training. CMMI is a framework for assessing and improving software systems. The researcher implemented the Goal Questions Metrics (GQM) model on two objectives and seven specific practices of the organizational training process area in CMMI. That's done to set measures. The researcher confirmed that the defined measures are the true measure for each one of the seven specific practices.
\end{abstract}

Keywords-Organizational training; training; measures; CMMI; GQM

\section{INTRODUCTION}

Improving human resources in any organization must be done by HR management [1].Organizational training (OT) aims to develop employees' knowledge and skills of the employee. It aims at enabling employees to carry out their functions efficiently and effectively. Itaims at enabling employees to meet the organization's business goals and satisfy the tactical training requirements [2].Measures accompanied with the first specific CMMI is a framework for assessing and improving software projects that are developed by the Software Engineering Institute (SEI) in Carnegie Mellon University in the United States. Goal Questions Metrics (GQM) paradigm was applied in the organizational training process area in CMMI. It was applied for defining the measures of specific goals and its specific practices.

Organizational training controls the training providedfor meetingthe organization's strategic business goals and the tactical training demands. It shall provide support to the teams responsible for carrying out the project.Training needs are identified by the support teams. Individual projectsare carried out to reach specific goals [2]. The main elements of the training process include written plans, a controlled training development program, and mechanisms for assessing the efficiency of the training elements. The main elements of the training process also include a team with an appropriate ability of disciplines and other areas of knowledge. Carrying out effective training requires identifying needs, having an instructional design, andproper training media and making plans. Naming thetraining requirements is based on the abilities and experiences required for performing the standard processes of the organization.Achieving success in training is manifested through the availability of chances for obtaining the knowledge and skills that are required to implement continuous and new activities.

Knowledge and skills can be organizational, contextual or technical. Contextual skills refer to the self-control, and contact capabilities and capabilities to hold interpersonal relations. Such skills are required for carrying out the work successfullyin the organization and the project. Having organizational skills shall positively affect the roles and responsibilities that are handled.Technical skills refer to the capabilities of using materials, data, equipment, tools and processes which are needed for carrying out a project or a process[2].

The organizational objectivescan be achieved byexecuting the strategies andtraining programs. That shall enhance the training process and facilitate it [3]. Training has an important impact on organizational promises [4]. Cheahet al. found that trainingcan significantly affect organizational commitment [5]. Achieving competitive advantage for organizations depends mainly on the trained human resource. Therefore, there is a need for observing the process of training employees and empowering them [1]. Job training and satisfactions shall affect the extent of having internal cooperation in the organization [6].

Measures are carried outfor carrying out processes or producing products [7]. Carrying out measures help us in understanding, controlling, and assessing processes and products [8]. It shall enable organizations to achieve the objectives sought from developing software [9] and [10].

It shall participate in managing the project [11]. It shall participate in assessing processes and products [12]. For developing a software process, there is a need to define the relevant attributes of the process. After that, there is a need to set the relevant metrics of these attributes.Measurement practices perform a significant role in managing and recognizing processes and products in computer information systems [13].

Through carrying out software measures, we assign numbers or symbols to the attributes of the selected objects in the actual life. That's done for determining the attributes by some defined rules [14]. Measures are important for project 
process understanding, managing, and change [15]. Measurement is carried out to assess the extent of accomplishing goals and supporting the improvement process [16] and [17].

We do notbelieve that we can define the reliable quantitative rules with having the same consistency and accuracy as physics' rules [18]. Precise metrics -like velocity and voltage- are rare in the software measures area. Software measurements are usually subject to argument [19]. There is a need for establishing a structure for effectiveness metrics [20].

A study was conducted by the Software Engineering Institute (SEI) in the mid-1980s about the capability of software developers. The study led to the development of a new framework which is a software capability maturity model for software (CMM/SW) [21]. The (CMMI) framework was introduced through the collaboration of the Software Engineering Institute (SEI) with several software companies. CMMI is a comprehensive structure. It's employed much for improving the processes of projects. That's done for producingproducts of high quality [22].

To ensure organizational survival and developing an effective strategy, it'simportant to adopt a CMMI model. This model will improve and assess the quality of the software [23]. Adopting a CMMI model will enable the organization to improve the project management and quality of the product. It will enable the organization to increase its production level. It will enable the organization to setthe project schedule and budget efficiently [24] and [25].

CMMI seeks to describeseveral software development process areas (PA). After the appraisal, CMMI determines the satisfaction of a process area. CMMI defines its activities and practices in a well-structured and easy manner[26]. CMMI includes all the activities that must be done for developing the software. It influences many products and processes in the life cycle of the software[27]. CMMI develops. It becomes a well-known, accepted standard of software process enhancement. It sheds light on several details [28].

Every process area in the CMMI framework has general goals. It is accompanied with general practices and specific goals and practices. A specific goal seeks to describe the things that must be done in the process area. Specific practice is considered as a central action in order for the concerned specific goal to be met. Specific practices in CMMI are considered goals[29] and [30]. Look at Fig. 1.

Goal-Question-Metric (GQM) is a manner for specifying the metrics. Basiliand Weiss [18] developed GQM in order to identify effective metrics forsoftware development activities.

This paper identifies measures for seven specific practices that are related to the two specific goals in the organizational training process area in CMMI-SW (Staged Representation) model within level 3. That is shown through Fig. 1. The GoalQuestion-Metrics method was applied to the seven specific practices which are accompanied with 2 objectives in the organizational training process. Through applying this method, the researcher defined a set of measures.

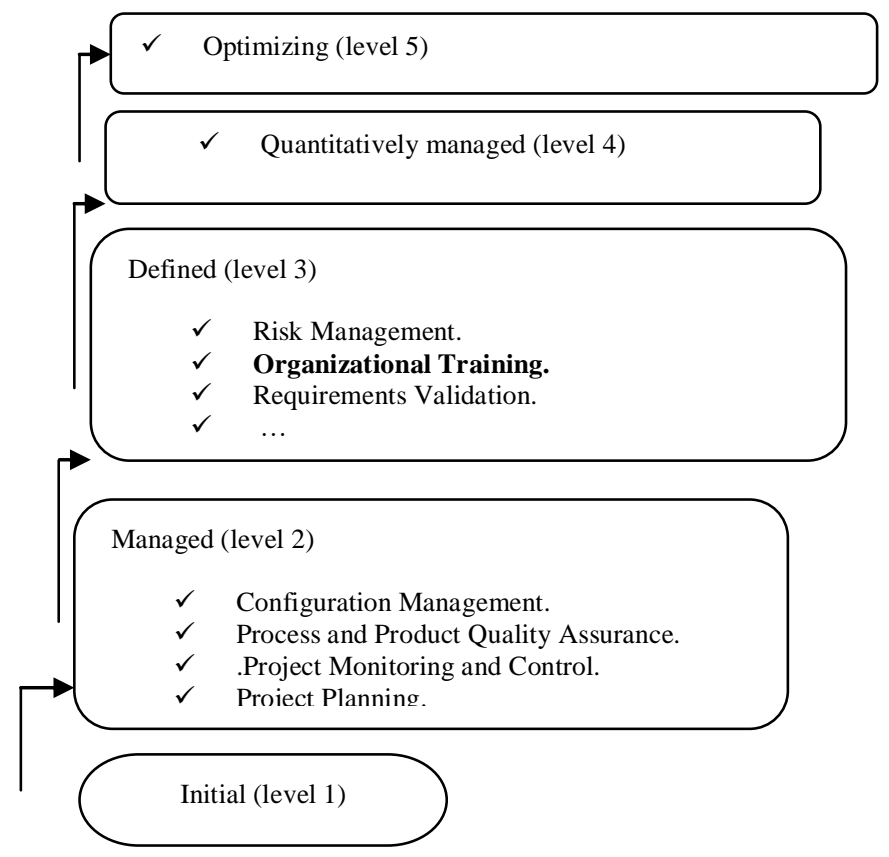

Fig. 1. The Five Maturity Levels in CMMI with Related Process Areas [2].

The researcher controlled and assessed processes and products in organizational training. That was done byusing a set consisting of defined measures. The next section presents the relevant work of the two frameworks CMMI and CMM.The fourth and third sections present a summary for the CMMI/SW and GQM respectively. The fifth section presents the implementation of the GQM to the seven specific practices that are accompanied with the two specific goals in the organizational training. That resulted in the definition of measures. The sixth section presents proof for the reliability and the validity of the defined measures. Sectionsevenpresents the study's conclusion.

\section{THE RELEVANT WORKS}

Various researches aimed to measure the software process that has been suggested, such as [21, 31-41]. The works that are related the most to our work are represented in the works of [21, 31, 32, 35-41]. Baumertand McWhinney[42] point out to several observations that are usefulfor measuring the practices (general characteristics) that are defined in the Capability Maturity Model for CMM/SW. The specified observations include 13 classes. These classes do not occur at all maturity levels. The work of Baumert and McWhinneydoesn't focus on a particular process. It shed a light on CMM instead of CMMI.

Several researchers studied measures of key process areas related to $\mathrm{CMM} / \mathrm{SW}$, but not to CMMI. Such researchers include Paulk [21] and Loconsole [13]. Paulkand others named several patterns that are related to a particular KPA. Naming such patterns is a Requirements Management. Their effortsfocus on a definite process (i.e. CMM/SW)rather than focusing on (CMMI/SW). Loconsole [13] specified several measures for a key process area in CMM/SW which is Requirements Management. Her work is concerned with 
(CMM/SW), rather than (CMMI/SW). Khraiwesh, [31, 35-39, 41] identifies a set of measures for processessuch as validation, process and product quality assurance, risk management, project planning, project monitoring and control, and configuration management in CMMI/SW.

The present study provides a description of a set of general measures for the organizational training process in $\mathrm{CMMI} / \mathrm{SW}$. The measures we chose are related to the seven specific practices which are accompanied by 2 goals in the organizational training process.

\section{OVERVIEW OFTHE CMMI-SW}

There are five maturity levels in the CMMI/SW (Staged Representation): Initial, managed, defined, quantitatively managed and optimizing levels. There are several process areas in each level of the 5 levels, except for the first level [2].

A process area has specific goal/ goals with related specific practices. It also has general goals with related general practices. Regarding each specific goal, it controls several features. That's done for performing the process area. As for each practice, it represents an action that must be carried out to meet the associated specific goal [2]. A generic goal holds proper institutionalization exercises. That's because each goal is accompanied with different processes named (generic). That's seen through Fig. 2.

The researcher presented below 2goals. He presented practices that are related to each specific goal in the organizational training process:

1). Establish an organizational training capability:-

a) Establish strategic training needs.

b) 1.2Identify which the organization must meet training needs.

c) 1.3 Create an organizational training tactical plan.

d) 1.4 Establish a training capability.

2). Provide training:-

a) 2.1 Deliver training.

b) 2.2 Create training records.

c) 2.3 Assess the effectiveness of the training.

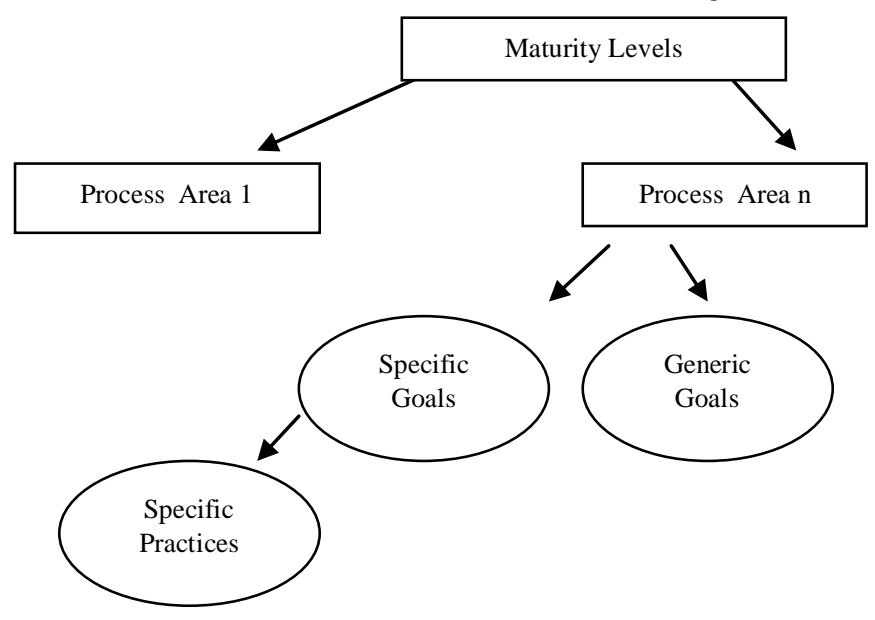

Fig. 2. Specific and Generic Goals.

\section{OVERVIEW ABOUT THE GQM}

Organizations use the Goal/Question/Metric (GQM) paradigm for concentrating on the measures of their objects. Any organization should identify the goals before collecting data when employing the GQM model [12]. After defining goals, the quantifiable questionsrelated to each goalmust be defined. After that, a set of measures associated with each questionmust be defined. After that, data should be collected to meet the goals.

The three steps in the GQM model are listed below:

1). Defining a set of objects that are linked to the requirements in the organization's projects [42].

2). Generating a set of quantifiable questions that are accompanied with each defined object. Various sets of instructions must be used to analyze the questions that were defined by Basili and Rombach [12].

3). Generating a set of measures which are fit to the quantifiable questions. That must be done in order for the generated measures to present information. That shall provide answers to the quantifiable questions. Many measures perhaps specified for one goal. A measure may refer to various questions.

\section{APPLyING GQM TO THE CMMI-SW}

The organizational training process in CMMI/SW has 2 specific goals and 7 related specific practices. In the present study, the researcher treated specific practices as being goals. These goals shall be met through the GQM model.

The organizational training process has the following seven specific practices:

1). Establish strategic training needs: Building and managing the main training requirements of the organization.

2). Identity which training needs are the responsibilities of the organization: Deciding which training requirements must be met by the organization and determining which requirements should be met through the individual project.

3). Establish an organizational training tactical plan: Building and managing the tactical plan of the organizational training needs.

4). Establish a training capability: Building and maintaining a training ability to mark the organizational training needs.

5). Deliver training: Releasing training after establish the organizational training tactical plan.

6). Create training records:Building and managing the documents of organizational training.

7). Assess training effectiveness: Assessing the impact of the training program of the organization.

As it ismentioned earlier, the seven specific practices shall be treated as goals. Following the GQM process, a set of quantifiable questions shall be produced. After that,a definition shall be provided for a set of measures that provide the required quantitative data for satisfying the produced questions. The work products and the sub-practices thatare 
proposed in each of the seven specific practices shall be taken into account when the measures are determined.

The tables below (i.e. Tables I-VII) describe a set of measures and questions. Every table describes a specific practice (i.e. a goal). The questions and measures are interfering. Each measure can offer information for clarifying several questions.

\section{A. Measures for Specific Practice 1}

Establish strategic training needs:Establish and maintain the strategic training needs of the organization.

Table I presents several measures and questions. Suchmeasures and questions are accompanied with the $1^{\text {st }}$ practice inthe OT.

\section{B. Measures for Specific Practice 2}

Identifying which training needs must be met by the organization:Identifying which training needs must be met by the organization and identifying which training needs must be met by the individual.

Table II presents measures and questions. Thesemeasures and questionsaccompanied with the $2^{\text {nd }}$ practice in OT.

\section{Measures for Specific Practice 3}

Establish organizational training tactical plan:Establish and maintain an organizational training tactical plan.

Table III presents measures and questions. Thesemeasures and questions are accompanied with the $3^{\text {rd }}$ practice in the OT.

TABLE. I. MEASURES AND QUESTIONS THAT ARE ACCOMPANIED WITH THE $1{ }^{\text {ST }}$ PRACTICE IN OT

\begin{tabular}{|c|c|c|}
\hline & Questions & Measures \\
\hline Q1 & $\begin{array}{l}\text { Do you classify the training needed for improving the } \\
\text { skills needed for carrying out the project activities? }\end{array}$ & $\begin{array}{l}\text { - Classify the training needed for improvingskills. } \\
\text { - \# Training needed classifications. } \\
\text { - \# Needed skills. (\# means the number of) }\end{array}$ \\
\hline Q2 & $\begin{array}{l}\text { Do you identify the training needed for developing the } \\
\text { information that's required for carrying out the project } \\
\text { activities? }\end{array}$ & $\begin{array}{l}\text { - Identifying the training needed for developing the information required to carry out the } \\
\text { project activities. } \\
\text { - \# Training needed classifications. } \\
\text { - \# Project activities. }\end{array}$ \\
\hline Q3 & $\begin{array}{l}\text { Do you build strategic training requirements? (Strategic } \\
\text { training requirements write long-term goals to develop } \\
\text { skills, normally from two to five years). }\end{array}$ & $\begin{array}{l}\text { - Building strategic training requirements. } \\
\text { - \# Long term goals. } \\
\text { - \# Years. }\end{array}$ \\
\hline Q4 & $\begin{array}{l}\text { Do you define the sources of the strategic training } \\
\text { requirements? (Some of the sources include the standard } \\
\text { processes of the organization, risk analysisis,the } \\
\text { improvement plan of the organization, the strategic } \\
\text { business plan of organizations, and skill assessments). }\end{array}$ & $\begin{array}{l}\text { - Providing a definition for the sources of the strategic training requirements. } \\
\text { - \# Sources ofstrategic training requirements. }\end{array}$ \\
\hline Q5 & $\begin{array}{l}\text { Do you analyze the strategic business plan of the } \\
\text { organization and process improvement plan of the } \\
\text { organization to know possible training needs? }\end{array}$ & $\begin{array}{l}\text { - Analyzing the strategic business plan and process improvement plan of the } \\
\text { organization. } \\
\text { - \# Training needed classifications. } \\
\text { - \# Skills that are needed. }\end{array}$ \\
\hline Q6 & $\begin{array}{l}\text { Do you document the strategic training requirements of } \\
\text { the organization? }\end{array}$ & $\begin{array}{l}\text { - Documenting the strategic training requirements of the organization. } \\
\text { - \# The requirements ofstrategic training. }\end{array}$ \\
\hline Q7 & $\begin{array}{l}\text { Do you classify the strategic training requirements of the } \\
\text { organization? (Some examples of categories are: } \\
\text { requirements analysis, quality engineering, testingteam } \\
\text { building, disaster recovery, leadership, analysis and } \\
\text { documentation, and negotiation skills). }\end{array}$ & $\begin{array}{l}\text { - Classifying the strategic training requirements of the organization. } \\
\text { - \# The requirements of strategic training. }\end{array}$ \\
\hline Q8 & $\begin{array}{l}\text { Do you define the skills and the roles needed for } \\
\text { performing the standard processes of the organization? }\end{array}$ & $\begin{array}{l}\text { - Defining the skills and roles needed to perform the standard processes of the } \\
\text { organization. } \\
\text { - \# Skills that are needed. } \\
\text { - \# Roles that are performed. }\end{array}$ \\
\hline Q9 & $\begin{array}{l}\text { Do you document the training needs forperforming the } \\
\text { roles in the standard processes of the organization? }\end{array}$ & $\begin{array}{l}\text { - Documenting the training needs for performing theroles in the standard processes of the } \\
\text { organization. } \\
\text { - \# Roles that are performed. }\end{array}$ \\
\hline Q10 & $\begin{array}{l}\text { Do you review the strategic needs of the organization and } \\
\text { the needed training as it is required? }\end{array}$ & $\begin{array}{l}\text { - Reviewing the strategic needs of the organization and the needed training as it is } \\
\text { required. } \\
\text { - \# Therequirements of strategic training. } \\
\text { - \# Skills that are needed. }\end{array}$ \\
\hline
\end{tabular}


TABLE. II. MEASURES AND QUESTIONSTHAT ARE ACCOMPANIED WITH THE $2^{\text {ND }}$ PRACTICE IN OT

\begin{tabular}{|c|c|c|}
\hline & Questions & Measures \\
\hline Q1 & $\begin{array}{l}\text { Do you decide which training is the responsibility of the } \\
\text { organization? (Organizational training related to the training } \\
\text { needs that are generally over projects). }\end{array}$ & $\begin{array}{l}\text { - Deciding which training is the responsibility of the organization. } \\
\text { - \# Training within the responsibility of the organization. }\end{array}$ \\
\hline Q2 & $\begin{array}{l}\text { Do you decide which training is the duty of the individual } \\
\text { projects? (projects have the main duty of recognizing their } \\
\text { training needs. }\end{array}$ & $\begin{array}{l}\text { Deciding which training is the duty of the individual projects. } \\
\text { - \# Training is the duty of the individual projects. }\end{array}$ \\
\hline Q3 & $\begin{array}{l}\text { Do you investigate the training needs that are determined by } \\
\text { the projects group? (For defining the general training needs } \\
\text { that can be addressed organization-wide). }\end{array}$ & $\begin{array}{l}\text { - Investigating the training needs that are determinedby theproject groups. } \\
\text { - \# Training needs that are determined by the project groups. }\end{array}$ \\
\hline Q4 & $\begin{array}{l}\text { Do you consult project groups about the way of meeting their } \\
\text { training needs? (Some examples of training offered by the } \\
\text { project group include training in the application, training in } \\
\text { the unique tools, and training in security and safety). }\end{array}$ & - Consulting project groups about the way of meeting their training needs \\
\hline Q5 & $\begin{array}{l}\text { Do you record promises for providing the project groups with } \\
\text { training? }\end{array}$ & $\begin{array}{l}\text { - Recording promises for providing training to project groups. } \\
\text { - \# Recorded promises for providing training. }\end{array}$ \\
\hline
\end{tabular}

TABLE. III. MEASURES AND QUESTIONSTHAT ARE ACCOMPANIED WITH THE $3^{\text {RD }}$ PRACTICE IN OT

\begin{tabular}{|c|c|c|}
\hline & Questions & Measures \\
\hline Q1 & $\begin{array}{l}\text { Do you develop a training tactical plan for the organization? } \\
\text { (Tactical plan refers to the plan set for delivering the training } \\
\text { that is the duty of the organization). }\end{array}$ & $\begin{array}{l}\text { - Development of a training tactical plan for the organization. } \\
\text { - \# The objectives of the tactical plan. }\end{array}$ \\
\hline Q2 & Do you determine the training subjects? & $\begin{array}{l}\text { - Determining the training subjects. } \\
\text { - \# The training subjects }\end{array}$ \\
\hline Q3 & $\begin{array}{l}\text { Do you set schedules based on the training actions and their } \\
\text { related issues? }\end{array}$ & $\begin{array}{l}\text { - Setting schedules based on the training actions and their related issues. } \\
\text { - \# The training subjects. }\end{array}$ \\
\hline Q4 & Do you set methods to be used for training? & $\begin{array}{l}\text { - Setting methods to be used for training. } \\
\text { - \# training methods. }\end{array}$ \\
\hline Q5 & $\begin{array}{l}\text { Do you set quality requirements and standardsfor the training } \\
\text { materials? }\end{array}$ & $\begin{array}{l}\text { - Settingquality requirements and standards for the training materials. } \\
\text { - \# Quality standards }\end{array}$ \\
\hline Q6 & $\begin{array}{l}\text { Do you determine the needed resources such as tools, } \\
\text { facilities, knowledge, skills, staffing, and the environment? }\end{array}$ & $\begin{array}{l}\text { - Determining the needed resources. } \\
\text { - \# The needed resources. }\end{array}$ \\
\hline Q7 & $\begin{array}{l}\text { Do you document the extent of commitments shown bythe } \\
\text { ones responsible for executing the plan? }\end{array}$ & $\begin{array}{l}\text { - Documenting the extent of commitments shown by the ones responsible for executing } \\
\text { the plan. } \\
\text { - \# The documented commitments. }\end{array}$ \\
\hline Q8 & Do you review the plan and commitments as required? & Reviewing the plan and commitments as required. \\
\hline
\end{tabular}

\section{Measures for Specific Practice 4}

Establish a training capability:Establish and maintain a training capability to address organizational training needs.

Table IV presents measures and questions. Thesemeasures and questions are accompanied with the $4^{\text {th }}$ practice in the OT.

\section{E. Measures for Specific Practice 5}

Deliver training:Deliver training following the organizational training tactical plan.

Table V presents measures and questions. Thesemeasures and questions are accompanied with the $5^{\text {th }}$ practice in OT

\section{F. Measures for Specific Practice 6}

Creating training records: Creating and maintaining the records oforganizational training.

Table VI presents measures and questions. Thesemeasures and questions areaccompanied with the $6^{\text {th }}$ practice in OT.

\section{G. Measures for Specific Practice 7}

Assess the training effectiveness: Assess the effectiveness of the organization's training program.

Table VII presents measures and questions. Thesemeasures and questions areaccompanied withthe $7^{\text {th }}$ practice in OT. 
TABLE. IV. MEASURES AND QUESTIONS THAT ARE ACCOMPANIED WITHTHE4 ${ }^{\text {TH }}$ PRACTICE IN OT

\begin{tabular}{|c|c|c|}
\hline & Questions & Measures \\
\hline Q1 & $\begin{array}{l}\text { Do you choose suitable methods for meetingthe demands of } \\
\text { organizational training? (Some examples of training methods } \\
\text { include facilitated videos, guided self-study, computer-aided } \\
\text { instruction,classroom training,and chalk talks). }\end{array}$ & $\begin{array}{l}\text { - Choosing the suitable methods to meet the organizational training demands } \\
\text { - \# The methods to be used for meeting organizational training demands }\end{array}$ \\
\hline Q2 & $\begin{array}{l}\text { Do you take into account the reasons that may affect the } \\
\text { selection of training methods, such asaudience-specific } \\
\text { knowledge, work environment, schedule, and costs? }\end{array}$ & $\begin{array}{l}\text { - Taking into account the reasons that may influence the selection of training methods. } \\
\text { - \# The methods to be used for meeting organizational training demands }\end{array}$ \\
\hline Q3 & $\begin{array}{l}\text { Do you decide whether to produce training materials inside } \\
\text { or outside the organization? (Some examples of measures } \\
\text { that can be used to decide, availability of training from } \\
\text { outside sources, availability of time to prepare for the project, } \\
\text { availability of internal expertise, and applicability to business } \\
\text { goals). }\end{array}$ & $\begin{array}{l}\text { - Deciding whether to produce training materials inside or outside the organization. } \\
\text { - \# Measures that can be used to decide. } \\
\text { - \# Inside produced material. } \\
\text { - \# Outside produced material. }\end{array}$ \\
\hline Q4 & Do you develop or acquire qualified lecturers? & $\begin{array}{l}\text { - Acquisition of development of qualified lecturers. } \\
\text { - \# Acquisition of qualified lecturers. } \\
\text { - \# Development of qualified lecturers. }\end{array}$ \\
\hline Q5 & $\begin{array}{l}\text { Do you describe the training in the training curriculum of the } \\
\text { organization? } \\
\text { (Some examples of description of each course include the } \\
\text { intended audience, training objectives, topics, prerequisites, } \\
\text { lesson plans, and length of the training). }\end{array}$ & $\begin{array}{l}\text { - Describing the training in the training curriculum of the organization. } \\
\text { - \# The intended audience. } \\
\text { - \# The training objectives. } \\
\text { - \# The prerequisites. } \\
\text { - The length of the training. }\end{array}$ \\
\hline Q6 & $\begin{array}{l}\text { Do you review the supporting artifacts and the training } \\
\text { materials as required? } \\
\text { (Some examples of conditions must be reviewed when } \\
\text { training needs change (e.g. due to the new technology). That } \\
\text { must be done after assessing the training results in need to } \\
\text { change (e.g. assessment for the training or instructors)). }\end{array}$ & $\begin{array}{l}\text { - Reviewing the supporting artifacts and training materials as needed. } \\
\text { - \# Training evaluations. } \\
\text { - \# Instructor evaluations. } \\
\text { - \# Supporting artifacts. } \\
\text { - \# Training needs change. }\end{array}$ \\
\hline
\end{tabular}

TABLE. V. MEASURES AND QUESTIONSTHAT AREACCOMPANIED WITH THE $5^{\mathrm{TH}}$ PRACTICE IN OT

\begin{tabular}{|c|c|c|}
\hline & Questions & Measures \\
\hline Q1 & $\begin{array}{l}\text { Do you take into account the required experience when you } \\
\text { choose somebody to be trained? }\end{array}$ & $\begin{array}{l}\text { - Taking into account the required experience. } \\
\text { - \# Trainers who have the required experience to receive training. } \\
\text { - \# Trainers who don't have the required experience to receive training. }\end{array}$ \\
\hline Q2 & $\begin{array}{l}\text { When you choose the trainees, do you take into account the } \\
\text { abilities and skills that trainees must have to perform their } \\
\text { roles? }\end{array}$ & $\begin{array}{l}\text { - Taking into account the skills and abilities that must be possessed by the trainees to do } \\
\text { their roles. } \\
\text { - \# The trainers who have the required abilities and skills to do their roles. } \\
\text { - \# The trainers who do not have the required abilities and skills to do their roles. }\end{array}$ \\
\hline Q3 & $\begin{array}{l}\text { Do you take into account the need to present a competency } \\
\text { addition to the crucial working area? }\end{array}$ & $\begin{array}{l}\text { - Taking into account the need to present competency for the crucial working area. } \\
\text { - \# Crucial working area. }\end{array}$ \\
\hline Q4 & $\begin{array}{l}\text { Do you choose people who will get the training needed for } \\
\text { doing their tasks efficiently? }\end{array}$ & $\begin{array}{l}\text { - Choosing people who will get the trainingneeded for doing their tasks. } \\
\text { - \# People chosen to get training }\end{array}$ \\
\hline Q5 & $\begin{array}{l}\text { Do you waive people who already possess the skills and } \\
\text { knowledge needed for doing their tasks? }\end{array}$ & $\begin{array}{l}\text { - Waiving people who already possess the skills, and knowledge needed for doing their } \\
\text { tasks. } \\
\text { - \# People who already possess skills. } \\
\text { - \# People who already possess knowledge. }\end{array}$ \\
\hline Q6 & $\begin{array}{l}\text { Do you schedule resources combined with training (e.g. } \\
\text { instructors, facilities)? }\end{array}$ & $\begin{array}{l}\text { - Scheduling resources combined with training. } \\
\text { - \# Instructors. } \\
\text { - \# Tools. }\end{array}$ \\
\hline Q7 & $\begin{array}{l}\text { Is the provided training consistent with the real } \\
\text { environment conditions? }\end{array}$ & $\begin{array}{l}\text { - Consistency between the provided training and real operation conditions. } \\
\text { - \# Training courses that are consistent with the real environmental conditions. }\end{array}$ \\
\hline Q8 & $\begin{array}{l}\text { Does the training involve activities that simulate the actual } \\
\text { work circumstance? }\end{array}$ & $\begin{array}{l}\text { - Involving activities that simulate the actual work circumstance. } \\
\text { - \# Activities that simulate the actual real work circumstance. }\end{array}$ \\
\hline Q9 & $\begin{array}{l}\text { Do you track the performance of the training based on the } \\
\text { plan? }\end{array}$ & $\begin{array}{l}\text { - Tracking the performance of training based on the plan. } \\
\text { - \# Contradictions with the plan. } \\
\text { - \# Agreements with the plan. }\end{array}$ \\
\hline Q10 & $\begin{array}{l}\text { Do you support the training within a feasible time after the } \\
\text { training was planned? }\end{array}$ & $\begin{array}{l}\text { - Supporting the training to be in a feasible time after the training was planned. } \\
\text { - The range of time the training will start. }\end{array}$ \\
\hline
\end{tabular}


TABLE. VI. MEASURES AND QUESTIONS THAT AREACCOMPANIED WITH THE $6{ }^{\text {TH }}$ PRACTICE IN OT

\begin{tabular}{|c|c|c|}
\hline & Questions & Measures \\
\hline Q1 & $\begin{array}{l}\text { Do you create and maintain documents about the } \\
\text { organization's training? }\end{array}$ & $\begin{array}{l}\text { - Creating and maintaining documents about the organization's training. } \\
\text { - \# Documents related to training }\end{array}$ \\
\hline Q2 & $\begin{array}{l}\text { Do you save the histories of every student who completes } \\
\text { each training course successfully or unsuccessfully? }\end{array}$ & $\begin{array}{l}\text { - Saving thehistories of every student who complete each training course successfully or } \\
\text { unsuccessfully } \\
\text { - \# The students who complete the training. } \\
\text { - \# The students who complete the training successfully. } \\
\text { - \# The students who unsuccessfully complete the training. }\end{array}$ \\
\hline Q3 & $\begin{array}{l}\text { Do you keep documents about every employee who } \\
\text { waived from training? }\end{array}$ & $\begin{array}{l}\text { - Keeping documents about every employee who waived from training. } \\
\text { - \# Documents about the employee who waived from training. }\end{array}$ \\
\hline Q4 & $\begin{array}{l}\text { Do you offer the training documents to the relevant } \\
\text { people for assignment purposes? }\end{array}$ & $\begin{array}{l}\text { - Offering the training documents to the relevant people for assignment purposes. } \\
\text { - \# Offeringthe training documents to students. }\end{array}$ \\
\hline Q5 & $\begin{array}{l}\text { Do you produce a skill matrix that includes records of } \\
\text { training? }\end{array}$ & $\begin{array}{l}\text { - Producing a skill matrix that includes records of training. } \\
\text { - Academic qualification } \\
\text { - \# Years of experience. } \\
\text { - \# Training sponsored by the organization. }\end{array}$ \\
\hline
\end{tabular}

TABLE. VII. MEASURES AND QUESTIONS THAT AREACCOMPANIED WITH THE $7^{\text {TH }}$ PRACTICE IN OT

\begin{tabular}{|c|c|c|}
\hline & Questions & Measures \\
\hline Q1 & $\begin{array}{l}\text { Do you distribute post-training surveys to the training } \\
\text { members to assess the training performance? }\end{array}$ & $\begin{array}{l}\text { - Distributing post-training surveys to the training members to assess the training } \\
\text { performance } \\
\text { - \# The training members that the post-training surveys were distributed to them }\end{array}$ \\
\hline Q2 & $\begin{array}{l}\text { Do you distribute the post-training surveys to managers for } \\
\text { assessing the training performance? }\end{array}$ & $\begin{array}{l}\text { - Distributing post-training surveys to managers for assessing the training performance. } \\
\text { - \# The managers that thepost-training surveys were distributed to them }\end{array}$ \\
\hline Q3 & $\begin{array}{l}\text { Do you use the outcomes of training evaluation to improve } \\
\text { the materials of training? }\end{array}$ & $\begin{array}{l}\text { - Using the outcomes of training evaluation to improve the materials of training. } \\
\text { - \# Improved course materials. }\end{array}$ \\
\hline Q4 & Do you ask the training participants to take an exam? & $\begin{array}{l}\text { - Making examinations for the training participants. } \\
\text { - \# The training participants who were Examined. }\end{array}$ \\
\hline Q5 & $\begin{array}{l}\text { Do you assess the projects (completed or in-progress or) to } \\
\text { identify whether the staff information is sufficient or not? }\end{array}$ & $\begin{array}{l}\text { - Assessing the projects. } \\
\text { - \#Completed evaluated projects. } \\
\text { - \# In-progress evaluated projects. }\end{array}$ \\
\hline Q6 & $\begin{array}{l}\text { Do you collect student evaluations about how the activities of } \\
\text { the training met their requirements? }\end{array}$ & $\begin{array}{l}\text { - Collecting student evaluations about how the activities of the training met their } \\
\text { requirements. } \\
\text { - \# Students with satisfying requirements. } \\
\text { - \# Students with unsatisfied requirements. }\end{array}$ \\
\hline
\end{tabular}

\section{VALIDITY AND RELIABILITY OF THE DEFINED MEASURES}

To proof the validity and reliability of the set of the defined measures linked to the Organizational training process $(\mathrm{OT})$, the researcher developed a questionnaire. The results obtained through the questionnaire were used to prove that the defined measures are really suitable for measuring the seven goals (specific practices). The researcher calculated the Cronbach alpha coefficient value through the SPSS.

Cronbach alpha coefficient valuescalculated formeasuring the inner coherence and consistency. It provides an answer to the following question: (Do all of the defined measures for each specific practice meet the same goal?) The values of the Cronbach alpha coefficient are within the range of 0 and 1 . The closer the value to 1 , the higher the inner consistency between the items shall be [20]. If the value is less than 0.5, the internal consistency between the items shall be considered low and unaccepted [20].
The researcher checked the validity of the questionnaire by passing it to academics working at the software engineering department at Zarqa University. The questionnaire was also passed to professionals (designers and programmers) who work atZarqa University. The researcher distributed the questionnaire in six software development institutions in Jordan. Three hundred questionnaire forms were retrieved. The questionnaire forms are filled by analysts, designers, and programmers. Each questionnaire consists of seven parts. Each part addresses a goal (specific practice) of the organizational training process (OT).

Asit's displayed through appendix A, every part includes a combination of statements (measures) that are linked to each goal (specific practice). Five multiple answers are provided, which are: strongly agree, agree, neither agree nor disagree, disagree, strongly disagree. The participant must choose one answer from these answers.

After calculating theCronbach Alpha coefficient values, the researcher obtained values that are within the range of 10.5 for the seven parts. These values are: $0.758,0.668,0.680$, 
$0.659,0.730,0.698$, and 0.767 . That means that the statements (measures) are consistent with one another, reliable and considered valid for measuring the seven specific practices. These practices are:

1). Establishing strategic training needs.

2). Identifying which training needsis the responsibility of the organization,

3). Establishing the organizational training tactical plan,

4). Establishing a training capability,

5). Delivering training,

6). Establishing training records,

7). Assessing the training effectiveness.

\section{CONCLUSION}

Through this paper, the researcher defined common measures for one important process in (CMMI-SW). Thisprocess is represented in organizational training. The researcher applied the Goal Question Metrics (GQM) model to seven relevant goals (specific practices) of organizational training. That was done for defining the measures.

The researcher confirmed that the defined measures are true measures for each one of the seven goals (specific practices). That's confirmed through using a questionnaire for proving the validity and the reliability of the set of measures that the researcher defined for the organizational training process (OT). The researcher calculated the Cronbach alpha coefficient value through the SPSS.

In this study, through using the combination of the defined measures, organizations shall have a valid method for checking the tasks related to the organizational training process. The researcher will have a mature organizational training process, provided that the defined measures in this paper get implemented. The set of the defined measures can be implemented for managing and assessing the project's products and processes in the OT.

In the future, other process areas in the capability maturity model integration (CMMI) will be analyzed and measured.

\section{REFERENCES}

[1] F. Rabbanikhah, A. M. Jaghagh, R. M. Gholizadeh, S. Sabouri, and S Alirezaei, "Analyzing effective factors in efficiency of organizational trainings (A Case Study: Employees of Ministry of Health and Medical Education)," International Journal of Humanities and Cultural Studies (IJHCS) ISSN 2356-5926, pp. 2136-2154, 2016.

[2] C. P. Team, Capability Maturity Model® Integration for Development Version 1.3 (Software Engineering Institute). 2010.

[3] A. M. Saks and L. A. Burke-Smalley, "Is transfer of training related to firm performance?," International Journal of Training and Development, vol. 18, no. 2, pp. 104-115, 2014.

[4] H. N. Ismail, "Training and organizational commitment: exploring the moderating role of goal orientation in the Lebanese context," Human Resource Development International, vol. 19, no. 2, pp. 152-177, 2016.

[5] C. S. Cheah, V. S. W. Chong, S. F. Yeo, and K. W. Pee, "An empirical study on factors affecting organizational commitment among generation X," Procedia-Social and Behavioral Sciences, vol. 219, pp. 167-174, 2016.

[6] C. J. Chang, "The Factors on Elderly Employment Project Outcome: Appropriation of work, Job Training Satisfaction, Intra-organizational Cooperation," International Journal of Social Science and Humanity, vol. 6, no. 1, p. 14, 2016.
[7] C. Ebert, "Software Measurement for Better Project and Process Quality," UPGRADE (the European Journal for the Informatics Professional), vol. 10, no. 5, 2009.

[8] O. Gómez, H. Oktaba, M. Piattini, and F. García, "A systematic review measurement in software engineering: State-of-the-art in measures," in International Conference on Software and Data Technologies, 2006: Springer, pp. 165-176.

[9] C. Jones, "Implementing a Successful Measurement," IT Metrics and Benchmarking: Part II, vol. 16, no. 11, p. 12, 2003.

[10] L. O. Ejiogu, "Five principles for the formal validation of models of software metrics," ACM SIGPLAN Notices, vol. 28, no. 8, pp. 67-76, 1993.

[11] B. Kitchenham, D. R. Jeffery, and C. Connaughton, "Misleading metrics and unsound analyses," IEEE software, vol. 24, no. 2, pp. 73-78, 2007.

[12] V. R. Basili and H. D. Rombach, "The TAME project: Towards improvement-oriented software environments," IEEE Transactions on software engineering, vol. 14, no. 6, pp. 758-773, 1988.

[13] B. Kitchenham, S. L. Pfleeger, and N. Fenton, "Towards a framework for software measurement validation," IEEE Transactions on software Engineering, vol. 21, no. 12, pp. 929-944, 1995.

[14] N. E. Fenton, R. W. Whitty, and Y. Iizuka, Software Quality Assurance and Measurement: A Worldwide Perspective. Itp-Media, 1995.

[15] N. Fenton and J. Bieman, Software metrics: a rigorous and practical approach. CRC press, 2014.

[16] R. E. Park, W. B. Goethert, and W. A. Florac, "Goal-Driven Software Measurement. A Guidebook," Carnegie-Mellon Univ Pittsburgh Pa Software Engineering Inst, 1996.

[17] V. Mahnic and N. Zabkar, "Measurement repository for Scrum-based software development process," in Conference on computer Engineering and Application (CEA, 08) Acapulco, Mexico, 2008.

[18] L. C. Briand, S. Morasca, and V. R. Basili, "An operational process for goal-driven definition of measures," IEEE Transactions on Software Engineering, vol. 28, no. 12, pp. 1106-1125, 2002.

[19] R. S. Pressman, Software engineering: a practitioner's approach. Palgrave Macmillan, 2005.

[20] D. George, "Mallery. 2003. SPSS for Windows step by step: A simple Guide and reference 11.0 Update," ed: Allyn and Bacon. Boston.

[21] M. C. Paulk, C. V. Weber, S. M. Garcia, M. B. Chrissis, and M. Bush, "Key practices of the capability maturity model for software, version 1.1," Pittsburgh, PA: Software Engineering Institute (SEI), 1993.

[22] A. Pyster, "What beyond CMMI is needed to help assure program and project success?," in Software Process Workshop, 2005: Springer, pp. 75-82.

[23] P. Monteiro, R. J. Machado, R. Kazman, C. Simões, and P. Ribeiro, "RUP Alignment and Coverage Analysis of CMMI ML2 Process Areas for the Context of Software Projects Execution," in International Conference on Software Quality, 2014: Springer, pp. 214-228.

[24] Y. Lee and J. Chen, "Experience in introducing CMM to a telecommunication research organization," Journal of software engineering studies, vol. 1, no. 1, pp. 8-16, 2006.

[25] H.-C. Young, T. Fang, and C. Hu, "A successful practice of applying software tools to CMMI process improvement," Journal of Software Engineering Studies, vol. 1, no. 2, pp. 78-95, 2006.

[26] Z. D. Kelemen, R. Kusters, J. Trienekens, and K. Balla, "Towards complexity analysis of software process improvement frameworks," Budapest, Technical Report TR201301, 2013.

[27] W. Xiong and Y. Cao, "Comments on Software Process Improvement Methodologies Using QFD," Applied Mathematics \& Information Sciences, vol. 7, no. 3, p. 1137, 2013.

[28] W. E. Wong and T. Ma, Emerging technologies for information systems, computing, and management. Springer, 2013.

[29] C.-S. Wu and D. B. Simmons, "Software Project Planning Associate (SPPA): a knowledge-based approach for dynamic software project planning and tracking," in Proceedings 24th Annual International Computer Software and Applications Conference. COMPSAC2000, 2000: IEEE, pp. 305-310. 
[30] G. Xu, H. Hu, P. Yu, J. Lv, P. Qu, and M. Zhu, "Supporting flexibility of the CMMI process framework with a multi-layered process model," in 2013 10th Web Information System and Application Conference, 2013: IEEE, pp. 409-414.

[31] M. Khraiwesh, "Requirements Validation Measures in CMMI," World of Computer Science and Information Technology Journal (WCSIT), vol. 1, no. 2, pp. 26-33, 2011.

[32] J. H. Baumert and M. S. McWhinney, "Software measures and the capability maturity model," CARNEGIE-MELLON UNIV PITTSBURGH PA SOFTWARE ENGINEERING INST, 1992.

[33] T. F. Hammer, L. L. Huffman, L. H. Rosenberg, W. Wilson, and L. E. Hyatt, "Doing requirements right the first time," CROSSTALK The Journal of Defense Software Engineering, pp. 20-25, 1998.

[34] D. Janakiram and M. Rajasree, "Request: Requirements-driven quality estimator," ACM SIGSOFT Software engineering notes, vol. 30, no. 1, p. 4,2005 .

[35] M. Khraiwesh, "Risk management measures in CMMI," International Journal of Software Engineering \& Applications, vol. 3, no. 1, p. 149, 2012.

[36] M. Khraiwesh, "Project Planning Measures in CMMI," International Journal of Software Engineering \& Applications, vol. 4, no. 2, p. 103, 2013.

[37] M. Khraiwesh, "Process and product quality assurance measures in CMMI," International Journal of Computer Science and Engineering Survey, vol. 5, no. 3, p. 1, 2014.

[38] M. Khraiwesh, "Integrated project management measures in CMMI," International Journal of Computer Science and \& Information Technology (IJCSIT), vol. 7, no. 5, 2015.

[39] M. Khraiwesh, "Configuration Management Measures in CMMI," International Journal of Applied Engineering Research, vol. 12, no. 18, pp. 7546-7557, 2017.

[40] A. Loconsole, "Measuring the requirements management key process area," in Proceedings of ESCOM-European Software Control and Metrics Conference, London, UK, 2001, pp. 67-76.

[41] M. Khraiwesh, "Project Monitoring and Control in CMMI, Project Monitoring and Control Measures in CMMI," International Journal of
Computer Science \& Information Technology (IJCSIT) Vol, vol. 5, 2013.

[42] V. Caldiera and H. Rombach, "Goal Question Metric Paradigm, Encyclopedia of Software Engineering," ed: Wiley: Hoboken, NJ, USA, 1994.

\section{APPENDIX A}

A. Questionnaire And AnalysisQuestionnaire:

The table below presents a questionnaire that is constructed for theorganizational training process. Organizational training aimed at developing employees' knowledge and skills. It shall enable employees to carry out their duties efficiently and effectively.

The organizational training process has the following goals:

1). Establish strategic training needs.

2). Identify which training needs must be met by the organization.

$3)$. Create an organizational training tactical plan.

4). Establish a training capability.

5). Deliver training.

6). Create training records.

7). Assess the effectiveness of the training.

To estimate the fulfillment of the defined specific practices (goals), we will determine a few sentences linked to each specific practice. The collected information from these sentences will help us in the realization of the above seven goals.

Please, fill the form by writing down $(\sqrt{ })$ in a suitable position. Responding to the related question: do you see that the following statements possess an impact on the realization of the related specific practice (goal)?

Goal1: Establish strategic training needs.

(Do you see that these sentences can be used to check the achievement of goal1: Establish strategictrainingneeds?)

\begin{tabular}{|c|c|c|c|c|c|c|}
\hline $\begin{array}{l}\text { Statement } \\
\text { Serial }\end{array}$ & Statements & $\begin{array}{l}\text { Strongly } \\
\text { agree }\end{array}$ & Agree & $\begin{array}{l}\text { Neither agree } \\
\text { nor disagree }\end{array}$ & disagree & $\begin{array}{l}\text { Strongly } \\
\text { disagree }\end{array}$ \\
\hline 1 & $\begin{array}{l}\text { Classifying the training needed for improving the skills for carrying out the } \\
\text { project activities. }\end{array}$ & & & & & \\
\hline 2 & $\begin{array}{l}\text { Identifying the training needed for developingthe information required for } \\
\text { carrying out the project activities. }\end{array}$ & & & & & \\
\hline 3 & Buildingstrategic training requirements. & & & & & \\
\hline 4 & Defining the sources of strategic training requirements. & & & & & \\
\hline 5 & $\begin{array}{l}\text { Analyzing the strategic business plan of the organization and process } \\
\text { improvement plan of the organization to know possible training needs. }\end{array}$ & & & & & \\
\hline
\end{tabular}

